\title{
The Role of a Region in the Implementation of Innovative Projects for Non-Defence High-Technology Production
}

\author{
lurii V. Erygin*a and Elena V. Borisovab \\ ${ }^{a}$ Reshetnev Siberian State University of Science and Technology \\ Krasnoyarsk, Russian Federation \\ ${ }^{b}$ Joint Stock Company "Krasnoyarsk Machine Building Plant" \\ Krasnoyarsk, Russian Federation
}

Received 14.11.2019, received in revised form 03.03.2020, accepted 10.04.2020

\begin{abstract}
The article discusses the problems of involving the innovative potential of enterprises of the military-industrial complex in the implementation of innovative projects for the non-defence high-technology production, as well as determining the role and place of the regional innovation infrastructure in their implementation. The aim of the study is to justify the role of a region in the implementation of innovative projects for the non-defence high-technology production, to determine features and formulate requirements for the development of the regional innovation infrastructure that provides support for these innovative projects based on the interaction of the regional innovation system enterprises with the military-industrial complex and infrastructure facilities at the national and international levels. As a result of the study, the authors highlighted the most important areas of interaction between the enterprises of the military-industrial complex and the region's innovative infrastructure facilities (raising funds, promoting high-tech civilian products to national and international markets, etc.) and formulated the requirements for its formation. The results of the study can be used in managing the innovative development of the regions where high-tech enterprises of the militaryindustrial complex are located.
\end{abstract}

Keywords: military-industrial complex, innovative infrastructure of a region, innovative projects for the non-defence high-technology production, interaction.

Research area: innovation management.

Citation: Erygin, Iu.V., Borisova, E.V. (2020). The role of a region in the implementation of innovative projects for non-defence high-technology production. J. Sib. Fed. Univ. Humanit. Soc. Sci., 13(4), $477-$ 486. DOI: $10.17516 / 1997-1370-0583$.

(C) Siberian Federal University. All rights reserved

* Corresponding author E-mail address: yuri_erygin@mail.ru, borisovaev2015@mail.ru ORCID: 0000-0002-0609-1412 (Erygin); 0000-0001-5137-6882 (Borisova) 


\section{Introduction}

At present, high-tech enterprises of the military-industrial complex with a significant innovative potential play a leading role in the country's innovative development and are able to ensure both national security and the solution of the tasks set by the Government of the Russian Federation to increase the share of non-defence high-technology products to $50 \%$ by 2030 (Message from the President..., 2016), thereby developing their innovative and economic potential.

Given the current trends and conditions of innovative development, the effective use of the existing innovative potential of the enterprises of the military-industrial complex (MIC) in the non-defence high-technology production can become the main one for its functioning in order to ensure the country's defence capability, increase stability and efficiency of the economy, both of the MIC enterprises and the economy of the regions where these enterprises are located, which determines the relevance of the study.

\section{Theoretical framework}

The theoretical basis of the study is the works of foreign and Russian scientists on the problems of the formation and development of regional innovation systems, including the innovative infrastructure, as well as the innovative development of the MIC enterprises and the use of their innovative potential in the production of the non-defence high-technology products.

The requirements formulated in the article for the formation of the innovative infrastructure of a region develop the existing theoretical ideas about its structure, which are set forth in the works of D.D. Dorzhieva (Dorzhieva, 2009: 9), A.A. Vishniakov (Vishniakov, Shikhverdiev, 2008: 33), L.G. Elkina (Elkina, 2015: 96-97), N.N. Maksimov (Maksimov, 2013: 345), M.V. Rakhova (Rakhova, 2009: 290-291), P.A. Shikhverdiev (Vishniakov, Shikhverdiev, 2008: 33) and others, and serve as the basis for the development of a new conceptual approach to the formation of the innovative infrastructure of a region, providing support for the production and sales of the non-defence high-technology products.

\section{Statement of the problem}

The issues of formation of the innovative infrastructure in a region, which provide conditions for the development of non-defence high-technology products in a region and the integration of the MIC enterprises in the market economy, are still insufficiently developed, which justifies the need for the development of theoretical principles and methodological tools for building an innovative infrastructure in a region taking into account the specifics of production and sales of the non-defence high-technology products.

\section{Methods}

The study used general scientific research methods, including survey methods, system and comparative analysis, which allowed to ensure the relevancy of the results and conclusions of the study.

\section{Discussion}

In the course of the study, in order to assess the possibility of increasing the share of non-defence high-technology products, the authors analysed the high-tech enterprises of the leading MIC enterprises and the level of innovative development of the regions where they are located. Indicators of the level of innovative development of the regions where the high-tech MIC enterprises (corporations) are located are presented in Table 1.

The results of the analysis of the data in Table 1 indicate a slight effect of the production of non-defence high-technology products of MIC enterprises on the level of innovative development of regions. Along with this, the values of the regions' export shares and hightech products indicate the presence of the export potential of high-tech products manufactured by the MIC enterprises and, as a rule, its insignificant share in the region's exports.

The conclusion is supported by the results of the correlation analysis, which showed that the share of the high-tech products export and the region's export share are negatively correlated (the correlation coefficient is mi- 


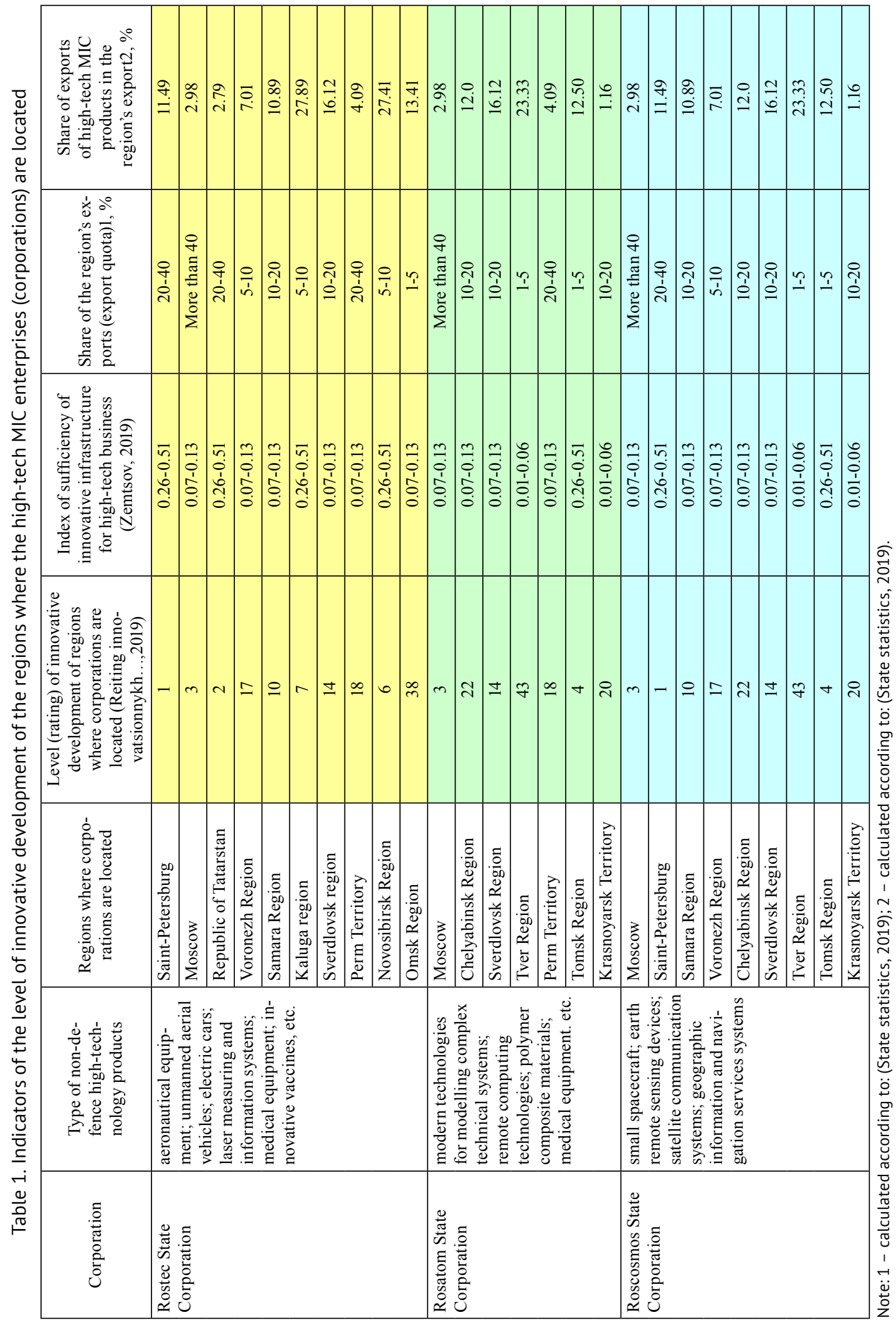


nus 0.59), and that the index of sufficiency of the region with an innovative infrastructure for the development of high-tech business has a weak effect on the export share of high-tech products of the MIC enterprises (correlation coefficient is 0.31 ).

The conclusion is also confirmed by the results of a survey conducted during a study among 59 organizations, including enterprises of Roscosmos State Corporation, innovative infrastructure facilities and development institutions.

As shown by the results of the survey, in half of the surveyed enterprises the share of innovative non-defence products does not exceed $10 \%$ in the total volume of production, as for the other half of the respondents - it does not exceed $5 \%$.

According to the defence industry enterprises, by 2025, an additional increase in the share of innovative non-defence products, including high-tech products, can raise from $10 \%$ to $25 \%$ (Fig. 1), which will increase the value of this indicator to $20-35 \%$ at $38 \%$ planned by the Government of the Russian Federation in 2025 and $39.2 \%$ in 2027 (Decree of the Government, 2019).

Deviation of the expected level of the share of the innovative non-defence products from the planned one is caused, first of all, by the underdevelopment of certain competencies of the MIC enterprises for the implementation of the full innovation cycle for the production of the high-tech non-defence products (attracting financing, promoting these products to national and international markets, etc.), as well as by the lack of financial and non-financial support for the MIC enterprises, as subjects of large high-tech business, by the institutes of development and the innovation infrastructure facilities existing in the regions.

The most popular type of support for the MIC enterprises provided by the innovation infrastructure facilities and development institutions is non-financial support $(98 \%$ of enterprises surveyed) (Fig. 2).

According to the results of the survey, the following are of great importance for the development of production of high-tech non-defence products of the MIC enterprises: the promotion of innovative products in national markets, as well as the stimulation of demand for innovative products and services (Fig. 3).

Thus, the results of the survey allow us to confirm the lack of existing support measures for the MIC enterprises, as subjects of a large high-tech business. When the MIC enterprises turned to innovation infrastructure facilities and development institutions for non-financial support, they received a $97 \%$ negative result (Fig. 4), which confirms the need to expand the possibilities of using the existing types of support for innovation infrastructure facilities and development institutions of the MIC enterprises as subjects of a large high-tech business.

The survey also made it possible to rank the objects of innovative infrastructure and development institutions in terms of the demand for their services by the MIC enterprises. Priorities are given to issues of commercialization, certification, licensing, export of manufactured high-tech non-defence products, etc. (Fig. 5)
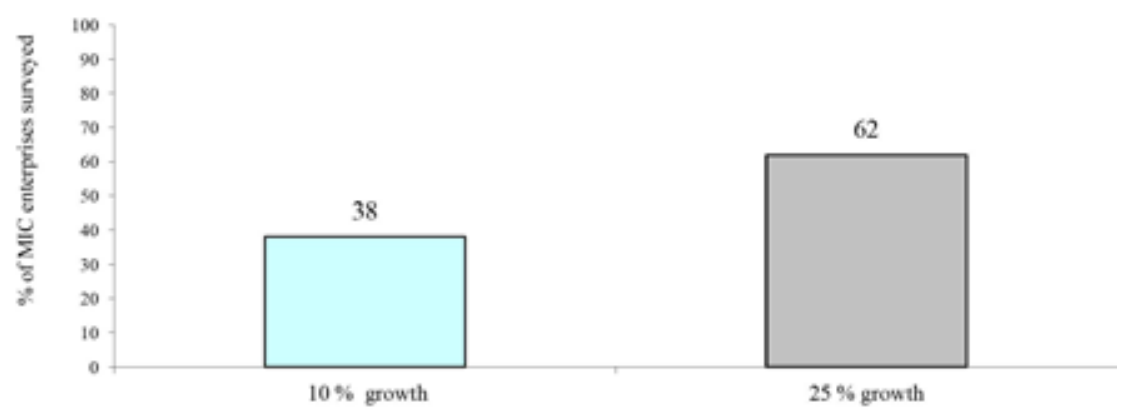

Fig. 1. Possible additional increase in the share of non-defence high-technology products in total production by 2025 , \% of enterprises surveyed 


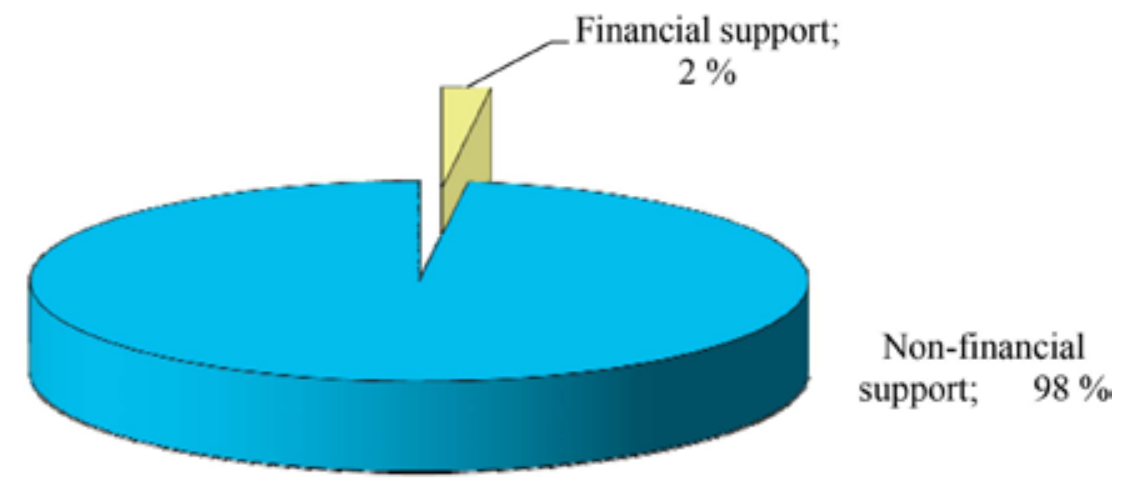

Fig. 2. The importance of types of support for the MIC enterprises, \% of enterprises surveyed

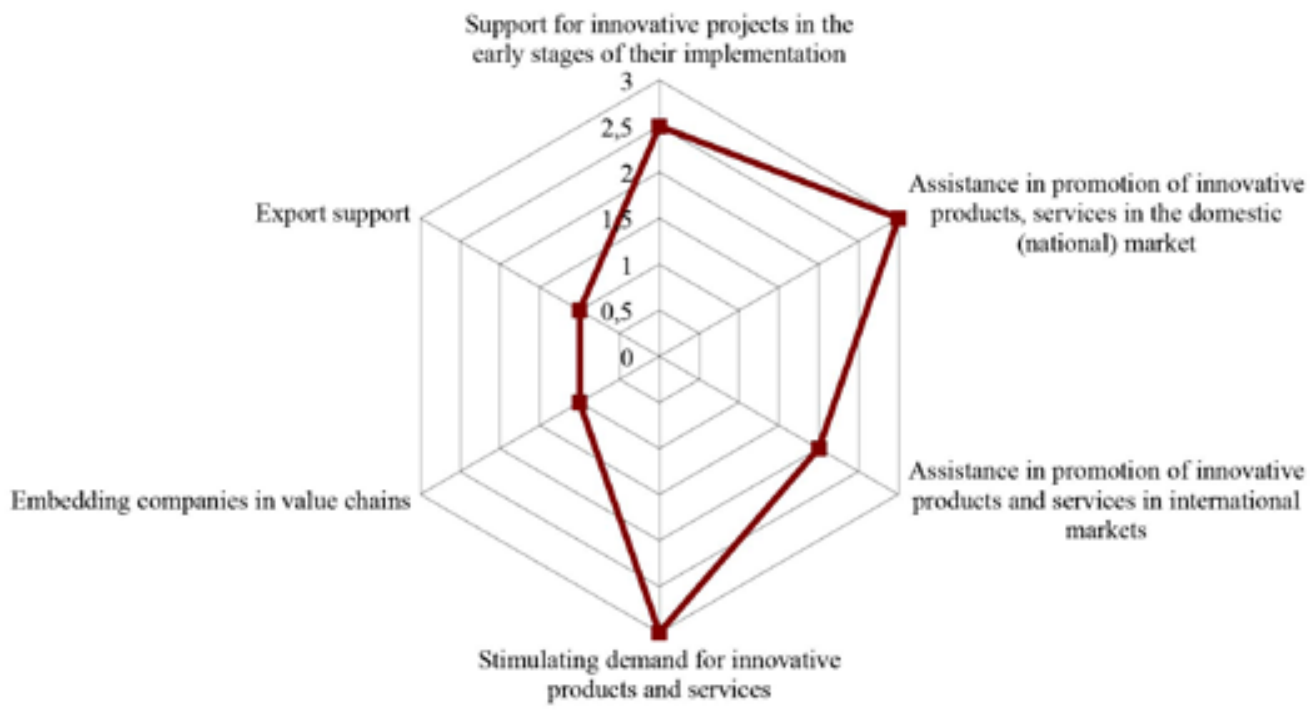

Fig. 3. The importance of types of non-financial support for innovative infrastructure and development institutions for the MIC enterprises.

Note: significance from 1 to 3, where 1 is low; 2 - average; 3 - high

The survey also revealed that the MIC enterprises, in the framework of the production of high-tech non-defence products, attach great importance to expanding cooperation in certain types of high-tech products and services with industry development institutions, innovative entities and innovative enterprises of related types of economic activity not included in the existing regional innovation infrastructure (Fig. 6).

The difficulty in expanding the cooperation between the MIC enterprises and various subjects of innovative activity is caused by the inaccessibility for the MIC enterprises as subjects of a large high-tech business, most of the financial and non-financial support measures provided by development institutions and innovative infrastructure subjects due to the predominant orientation of their activities towards supporting small and medium-sized enterprises.

A survey of regional subjects of innovation infrastructure, development institutions and other subjects of innovative activity confirms their predominant focus on supporting small and medium-sized enterprises.

At the same time, according to estimates of the surveyed subjects of innovation infrastructure, development institutions and other 


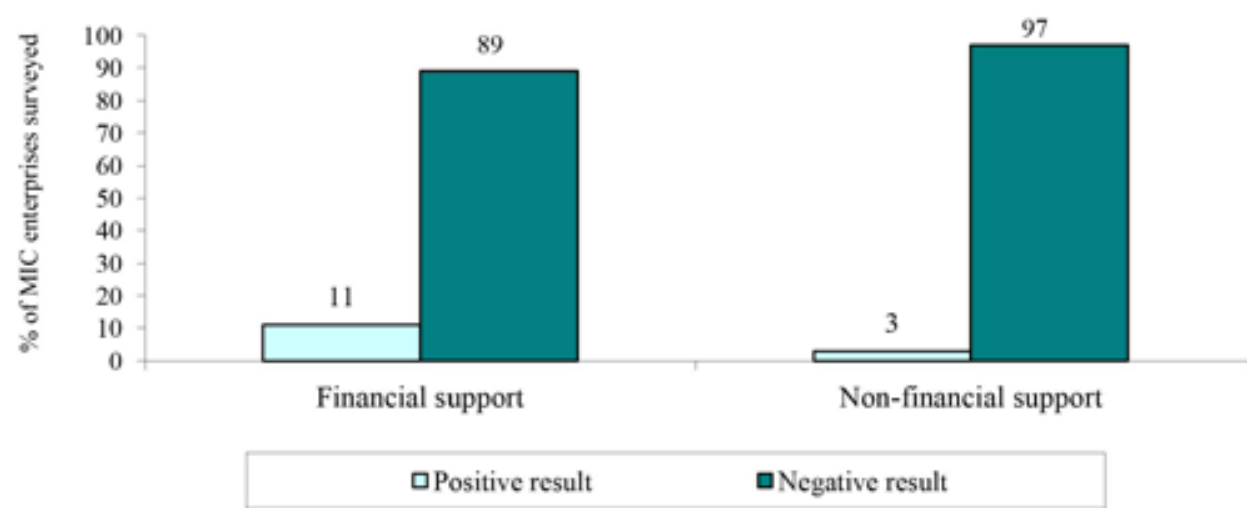

Fig. 4. The results of the appeal of the MIC enterprises to the subjects of innovation infrastructure and development institutions for support, \% of enterprises surveyed

0

5

10

Technology commercialization (innovation) centres

$\square$ 1

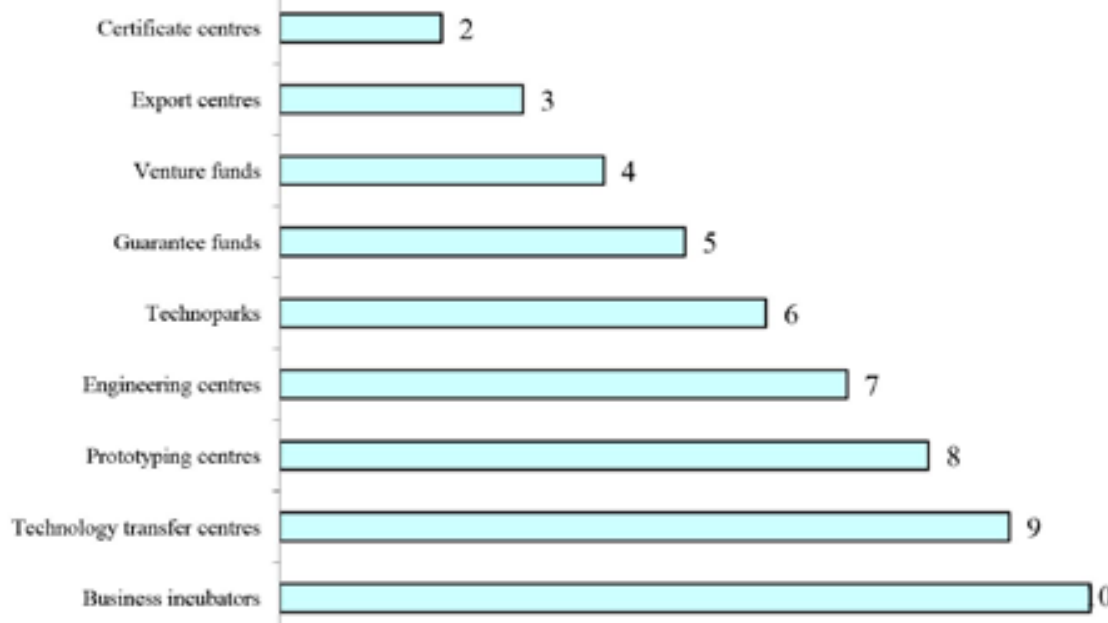

Fig. 5. Ranking of innovation infrastructure facilities by significance for the MIC enterprises. Note: significance is from 1 to 10 , where 1 is the most important, 10 is the least important subject of innovation infrastructure

subjects of innovative activity, including entities supporting the infrastructure of small and medium-sized enterprises, by 2025 the share of innovative products in the total gross regional product may increase to $20-35 \%$ (Fig. 7 ) due to the build-up of high-tech non-defence products by the MIC enterprises.

Herewith, subjects of small and medium-sized innovative entrepreneurship also confirm the possibility of developing their cooperation with the MIC enterprises in the framework of the production of certain types of high-tech non-defence products and services (Fig. 8) (75\% of the respondents).

\section{Conclusion / Results}

Thus, the solution of the task set by the Government of the Russian Federation to in- 


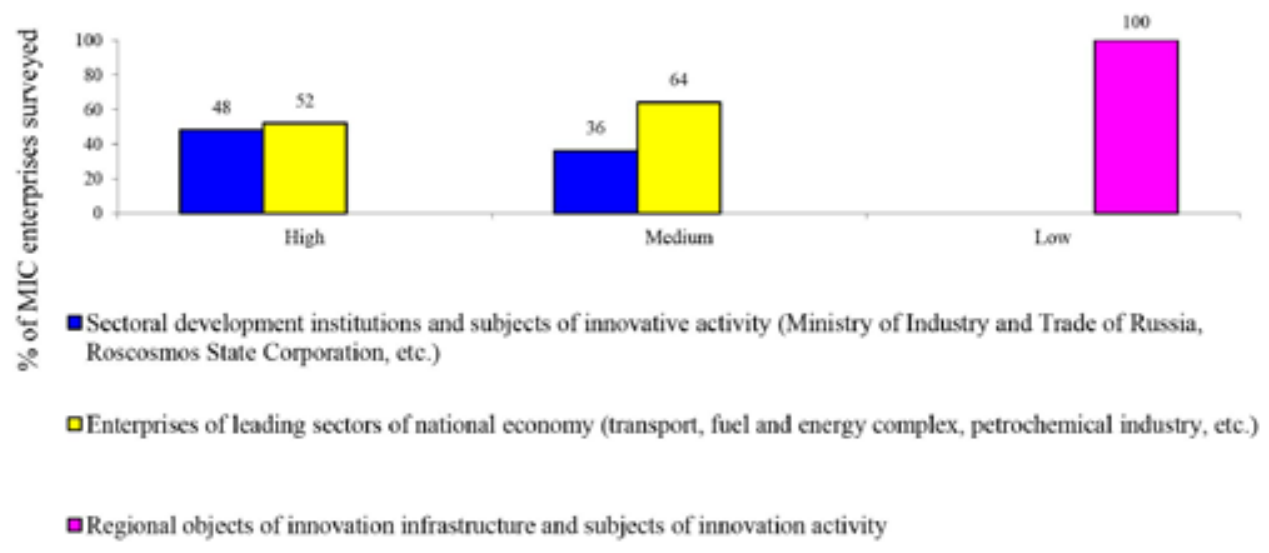

Fig. 6. The importance of expanding the cooperation of the MIC enterprises with subjects of innovative activity, \% of enterprises surveyed

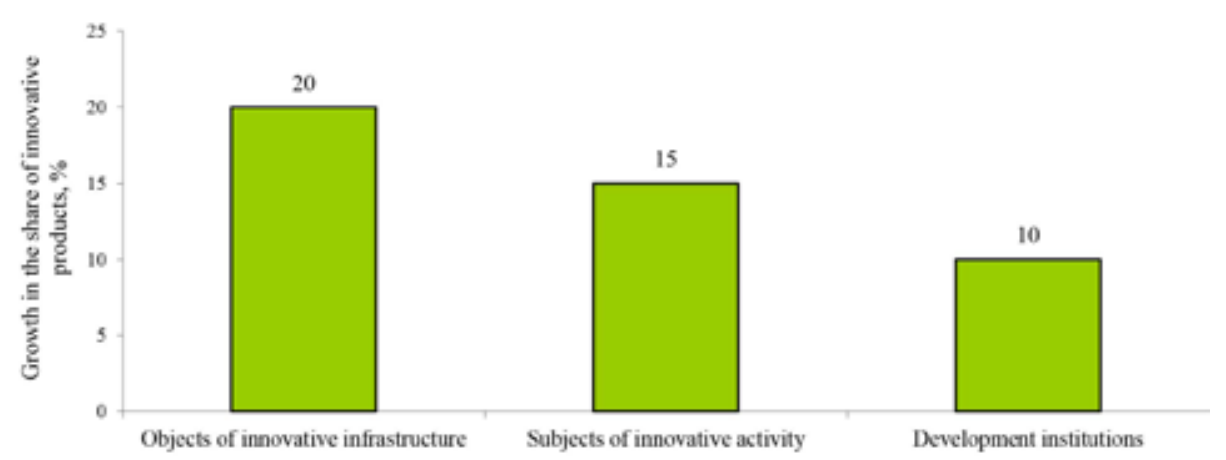

Fig. 7. Additional increase in the share of innovative products in the total gross regional product by 2025 due to innovations in large business (including the MIC enterprises), \%.

Note: Infrastructure entities supporting small and medium-sized enterprises answered "it is hard to say"

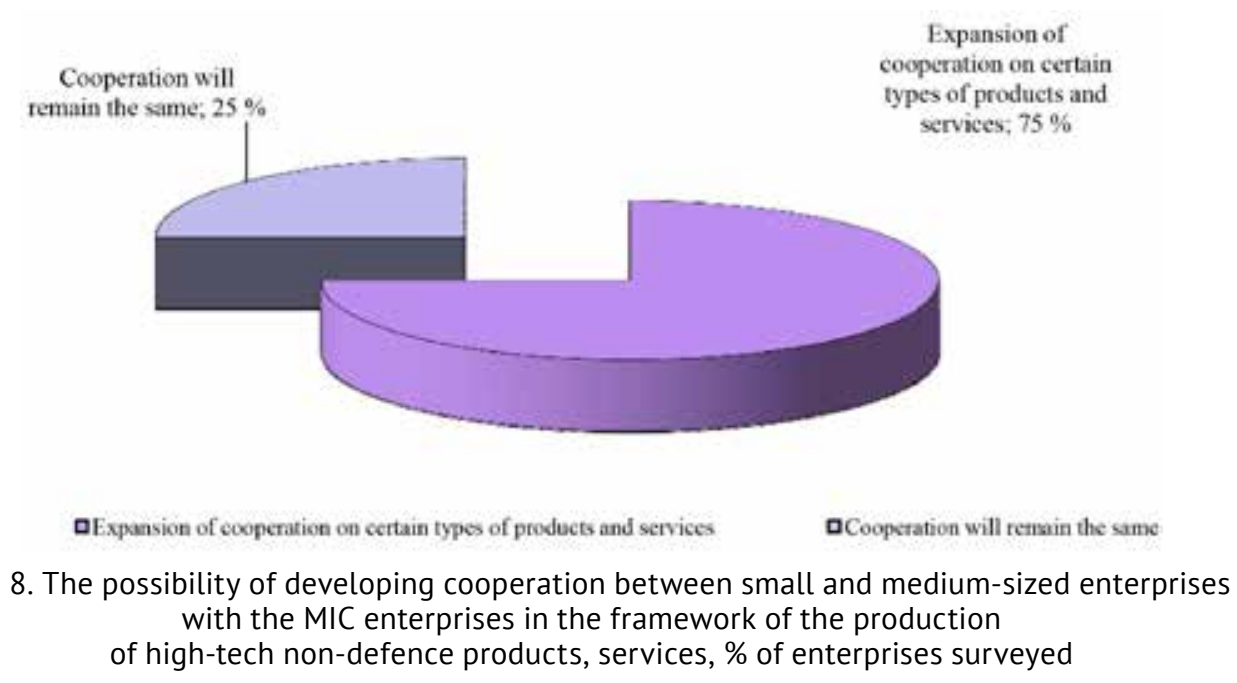


crease the share of high-tech non-defence products of the MIC enterprises is of great importance for the development of the economy of the regions where these enterprises are located. The results of the survey indicate that there is a significant growth potential for the share of high-tech non-defence products of the MIC enterprises (as large business entities) in the total gross regional product.

Increasing the production of high-tech non-defence products of the MIC enterprises determines the need to involve in the implementation of innovative projects related to the production of these products, both subjects of innovative activity in the region, primarily innovation infrastructure facilities, and the innovative potential of the MIC enterprises in order to realize the full innovation cycle of production of the high-tech non-defence products, which, of course, leads to the need to build interaction of subjects of the regional innovation system with enterprises of the defence industry and infrastructure projects of national and international levels in the implementation of some innovative projects of high-tech non-defence products.

The need to implement the full innovation cycle of the production of high-tech non-defence products increases the role of the regional innovation infrastructure in solving the problem, as a determining factor in the development of production of hightech non-defence products, and allows us to formulate requirements for the formation of the innovative infrastructure in the region, which take into account the need to involve the innovative potential of large MIC enterprises in the innovative activity of the region and provisions:

- compliance of the types of activities and functions of the innovation infrastructure facilities with the necessary competencies, ensuring the implementation of the full innovation cycle;

- organization of effective interaction of subjects of innovative activity at the regional, national and international levels in the implementation of innovative projects on the basis of partnership and responsibility;

- provision of targeted state support to all subjects of innovative activity - participants in the implementation of the full innovation cycle of production of high-tech non-defence products, subject to maximizing their commercial and budgetary effectiveness, as well as state incentives;

- possibility of increasing the number of participants in the implementation of an innovation project who have the status of an innovation infrastructure facility on an ongoing basis through the additional involvement of other innovation entities acquiring a temporary status as an innovation infrastructure facility (for the period of the innovation project implementation).

The implementation of the formulated requirements determines the need to develop a new conceptual approach to the formation of the innovative infrastructure of the region, which is the subject of further research.

\section{References}

Decree of the Government of the Russian Federation of February 6, 2019 No. 85-6 "On Amending the State Program of the Russian Federation" Development of the Military-Industrial Complex." Available at: http://www.consultant.ru/document/cons_doc_LAW_317786/a317f928f87598e0c39e3c6a836d5aee7ac45460/_(accessed 21 August, 2019).

Dorzhieva, D.D. (2009). Innovation infrastructure as a factor in the socio-economic development of the region: dissertation abstract $P h D$ in Economics. $22 \mathrm{p}$.

Elkina, L.G. (2015). Metodologicheskie osnovy formirovaniia i razvitiia innovatsionnoi infrastruktury regiona [Methodological foundations of the formation and development of the innovation infrastructure of the region]. Moscow. Bashkir State University, $160 \mathrm{p}$.

Maksimov, N.N. (2013). Osnovnye printsipy i zadachi innovatsionnoi deiatel'nosti organizatsii v sovremennykh usloviiakh [Basic principles and tasks of the innovative activity of organizations in modern conditions]. In Molodoi uchenyi [Young scientist], (10), 344-347. 
Message from the President to the Federal Assembly (2016). Available at: http://www.consultant.ru/ document/cons_doc_LAW_207978/(accessed 20 March, 2019).

Rakhova, M.V. (2009). Printsipy formirovaniia innovatsionnoi infrastruktury regiona [Principles of the formation of the innovative infrastructure of the region]. In Ekonomika obrazovaniia [Economics of Education], (3), Part 2, 283-291.

Reiting innovatsionnykh regionov Rossii [Rating of innovative regions of Russia] (2019). In Assotsiatsiia innovatsionnykh regionov Rossii [Association of innovative regions of Russia], $55 \mathrm{p}$.

Russian export center (2019). Available at: http://regionstat.exportcenter.ru/ (accessed 18 December, 2019).

State statistics (2019). Available at: https://www.fedstat.ru/indicator/ (accessed 21 December, 2019).

Vishniakov, A.A., Shikhverdiev, P.A. (2008). Problemy sozdaniia innovatsionnoi infrastruktury v severnom regione (na primere Respubliki Komi) [Problems of creating innovative infrastructure in the northern region (case of the Komi Republic)]. In Korporativnoe upravlenie i innovatsionnoe razvitie Severa: Vestnik Nauchno-issledovatel'skogo tsentra korporativnogo prava, upravleniia i venchurnogo investirovaniia Syktyvkarskogo gosudarstvennogo universiteta [Corporate governance and innovative development of the North: Bulletin of the Research Center for Corporate Law, Management and venture capital investment Syktyvkar State University], (4), 25-35.

Zemtsov, S.P. (2019). Natsional'nyi doklad "Vysokotekhnologichnyi biznes v regionakh Rossii" [National report "High-tech business in the regions of Russia"] In ANKhIGS, AIRR [Russian Presidential Academy of National Economy and Public Administration, Association of Innovative Regions of Russia], (2), $108 \mathrm{p}$. 


\title{
Роль региона в реализации
}

\section{инновационных проектов производства \\ высокотехнологичной гражданской продукции}

\author{
Ю.В. Ерыгинан, Е.В.Борисова ${ }^{6}$ \\ ${ }^{a}$ Сибирский государственный университет науки и технологий \\ имени академика М.Ф. Решетнева \\ Российская Федерачия, Красноярск \\ ${ }^{\circ} \mathrm{AO}$ «Красноярский машиностроительный завод» \\ Российская Федерачия, Красноярск
}

\begin{abstract}
Аннотация. В статье рассматриваются проблемы вовлечения инновационного потенциала предприятий оборонно-промышленного комплекса в реализацию инновационных проектов производства высокотехнологичной гражданской продукции, а также определения роли и места региональной инновационной инфраструктуры в их реализации. Целью проводимого исследования является обоснование роли региона в реализации инновационных проектов производства высокотехнологичной гражданской продукции, определении особенностей и формулировании требований к развитию региональной инновационной инфраструктуры, обеспечивающей поддержку данных инновационных проектов на основе взаимодействия объектов региональной инновационной системы с предприятиями оборонно-промышленного комплекса и инфраструктурными объектами национального и международного уровней. В результате исследования авторами выделены наиболее важные сферы взаимодействия предприятий оборонно-промышленного комплекса с объектами инновационной инфраструктуры региона (привлечение финансирования, продвижение высокотехнологичной гражданской продукции на национальный и международные рынки и др.) и сформулированы требования к ее формированию. Результаты исследования могут быть использованы в управлении инновационным развитием регионов размещения высокотехнологичных предприятий оборонно-промышленного комплекса.
\end{abstract}

Ключевые слова: оборонно-промышленный комплекс, инновационная инфраструктура региона, инновационные проекты производства высокотехнологичной гражданской продукции, взаимодействие.

Научная специальность: 08.00.05 - инновационный менеджмент. 